MARIUSZ MARKIEWICZ

UNIWERSYTET JAGIELLOŃSKI

\title{
Nowe spojrzenie na państwo \\ w czasach nowożytnych
}

W roku 1992 napisałem artykuł poświecony problemowi absolutyzmu w Europie nowożytnej, w którym przedstawiłem dyskusję historyków francuskich i anglosaskich dotyczacą tego zagadnienia ${ }^{1}$. W tamtym czasie wyraźnie już dominowało przekonanie, że termin ten nie oddaje trafnie rzeczywistości politycznej w czasach nowożytnych. Potwierdzały to przede wszystkim badania dotyczace funkcjonowania monarchii $z$ punktu widzenia lokalnych społeczeństw, dla których władza centralna miała nie tyle moc rozkazująca, ile jej polecenia stawały się dopiero przedmiotem negocjacji $z$ lokalnymi instytucjami. Także ostre przeciwstawianie sobie ustroju Francji jako przykładu absolutyzmu i Anglii jako monarchii ograniczonej, bardziej zaciemnia obraz niż pokazuje funkcjonowanie władzy $\mathrm{w}$ obu królestwach. W tym samym roku ukazała się ksiązka Nicholasa Henshalla o micie absolutyzmu, w której autor zakwestionował używanie tego terminu ${ }^{2}$, niestety dotarła ona do mnie już po opublikowaniu wspomnianego artykułu. Nicholas Henshall podsumowuje wspomniane ustalenia na temat monarchii francuskiej i angielskiej, podkreślając wielość ograniczeń jakie napotykała władza zwana absolutną. Ponadto twierdzi, że słowo absolutyzm nie było używane w czasach nowożytnych, natomiast stało się niezmiennym elementem opisu sytuacji politycznej w XIX w. Podkreśla, że pojawiło się w gazetach francuskich, które opisywały

${ }_{1}^{1}$ M. M a rki e w i c z, Absolutyzm, wymysł historyków czy rzeczywistość we Francji Ludwika XIV i Anglii Jakuba II, „Studia Historyczne” 1993, R. XXXVI, z. 4, (143), s. 451-463. Maszynopis złożony w styczniu 1992 r.

2 N. Henshall, The Myth of Absolutism. Change and Continuity in Early Modern European Monarchy, London 1992. 
konflikt w Hiszpanii w latach dwudziestych wieku XIX, gdzie absolutyzm występował jako przeciwstawienie liberalizmu ${ }^{3}$. Zwracał uwage, że biurokracja, armia, czy policja wieku XIX niewiele ma wspólnego $z$ podobnymi instytucjami w Europie starego ładu. Dwa lata później w Munsterze odbyła się międzynarodowa konferencja poświęcona państwu nowożytnemu, podczas której N. Henshall bronił swojej tezy, która wzbudziła wiele kontrowersji ${ }^{4}$. Wtedy też dobitnie i ironicznie zauważył, że "Absolutism" is an impressive excuse for sloppy thinking - which is why it will probably continue to be popular"5. Wydaje mi się, że używanie terminu absolutyzm jest adekwatne w opisie sytuacji politycznej w Europie wieku XIX, natomiast $\mathrm{w}$ stosunku do czasów nowożytnych powoduje liczne nieporozumienia. Oczywiście wielu historyków nadal używa tego terminu, chociaż coraz częściej pojawia się opinia, że należy raczej mówić o tendencji do tworzenia absolutyzmu niż o funkcjonowaniu takiego systemu przed wiekiem XIX.

Kwestionowanie używania pojęcia absolutyzm, rodzi naturalna potrzebę nazwania bytów politycznych, jakie funkcjonowały w Europie od XVI do XVIII w. W historiografii europejskiej zaakceptowana została koncepcja, opisująca ewolucję państw europejskich od „państw plemiennych” do „państw domeny”, gdzie dochody były oparte na domenie królewskiej i innych regaliach, które przekształciły się w „państwo podatków”, gdzie podstawowym źródłem utrzymania państwa sa podatki ${ }^{6}$. W tej dyskusji bardzo ważną rolę odegrała praca P.G.M. Dicksona, opisująca zjawisko rewolucji finansowej, która dokonała się w Anglii na przełomie XVII i XVIII w. ${ }^{7}$ Praca ta zwróciła uwage na zasadnicze znaczenie kredytu w wojnach prowadzonych w nowożytnej Europie. Owocowało to w spojrzeniu na charakter wojen toczonych w omawianym czasie i w określaniu wojen prowadzonych w „długim” osiemnastym stuleciu jako

3 Ibidem, s. 208.

${ }^{4}$ Por. Der Absolutismus - ein Mythos? Struktuwandel monarchisher Herrschaft in West - und Mitteleuropa (ca. 1550-1700), hrsg. R.G. Asch und H. Duchhardt, Köln 1996.

$5 \mathrm{~N}$. H e $\mathrm{n} \mathrm{s}$ h a 11, Early modern absolutism 1550-1700. Poitical reality or propaganda?, [w:] Der Absolutismus..., s. 53.

${ }^{6}$ H. S t o r r s, The Fiscal-Military State in the „Long” Eighteenth Century, [w:] The Fiscal-Military State in Eighteenth-Century Europe. Essays in honor of P.G.M. Dickson, ed. Ch. Storrs, Farnham 2009, s. 1.

7 P.M.G. D i ck s o n, The Financial Revolution in England. A Study in the Development of Public Credit 1688-1756, vol. I-II, New York 1967. 
konfliktów na wyczerpanie. Strona, która pierwsza przestraszyła się rosnącego długu publicznego i trudności w zdobyciu pieniędzy, występowała $z$ prośba o przerwanie działań wojennych ${ }^{8}$. Bardzo duże znaczenie ma także w dyskusjach nad państwem nowożytnym koncepcja „rewolucji militarnej”, która wprowadzona została do historiografii przez M. Robertsa ${ }^{9}$. Zaakceptowała ją większość badaczy, a dyskusja dotyczyła raczej pytania, kiedy ona nastapiła, a nie czy w ogóle do niej doszło.

W roku 1989 J. Brewer wprowadził do dyskursu historiograficznego termin „państwo fiskalno-militarne” dla określenia charakteru monarchii brytyjskiej w „długim” osiemnastym stuleciu10. W odróżnieniu od P.M.G. Dicksona zwracał większą uwagę na wzrost podatków w stosunku do dochodu narodowego Wielkiej Brytanii (14\% podczas wojny siedmioletniej) oraz na zwiększenie wpływów w Izbie Gmin ludzi związanych $z$ armia, marynarką wojenną i przemysłem zbrojeniowym ${ }^{11}$. Należy jednak podkreślić, że wielu historyków w dużym stopniu docenia znaczenie długu publicznego w systemie skarbowym Wielkiej Brytanii, gdyż finansował on od 20 do $40 \%$ wydatków wojennych. Ponadto przewaga Wielkiej Brytanii nad jej rywalka zza kanału polegała na bardzo sprawnym zarzadzaniu długiem państwowym. Przypomina się, że pod koniec wieku XVIII dług brytyjski w przeliczeniu na głowę mieszkańca był 15 razy większy niż we Francji, wynosił $182 \%$ dochodu narodowego, podczas gdy za kanałem było to tylko 56\%. Natomiast koszt obsługi długu we Francji był prawie dwa razy wyższy i obejmował $7,5 \%$ dochodu narodowego, gdy w Wielkiej Brytanii tylko 3,8\%12. J. Brewer ograniczył to określenie państwa nowożytnego do Wielkiej Brytanii, ale historycy zaczęli analizować także inne państwa pod kątem fiskalno-militarnym. Nie należy także zapominać, że historycy zajmujacy się badaniami nad absolutyzmem, podkreślali (np. Perry Anderson), że państwa absolutystyczne były przede wszystkim machinami przeznaczonymi do uży-

8 Por. np. P. Ke n nedy, Mocarstwa świata. Narodziny, rozkwit, upadek, Warszawa 1994, s. 45-146.

9 M. R o b e r t s, The Military Revolution, Belfast 1956.

10 J. B r ewe r, The Sinews of Power. War, Money and the English State, 1688-1733, London 1989.

11 Ibidem, s. 41.

$12 \mathrm{H}$. S c ott, The Fiscal-Military State and International Rivalry during the Long Eighteenth Century, [w:] The Fiscal-Military State..., s. 43. 
cia na polach bitew ${ }^{13}$. W roku 2009 ukazała się książka poświęcona P.G.M. Dicksonowi, która zawiera siedem artykułów, analizujacych ten problem w różnych państwach europejskich ${ }^{14}$.

Zarówno wydawca Christopher Storrs, jak i Hamish Scott, który w swoim eseju stara się podsumować dyskusję nad państwem fiskalno-militarnym, zauważaja, że w skali europejskiej w osiemnastowiecznej Europie można mówić o dwóch sposobach zapewnienia środków w celu prowadzenia wojny. Pierwszy to wspomniane państwo fiskalno-militarne dominujące na zachodzie Europy, drugi sposób, przeważający na wschodzie, to państwo militarnofiskalne ${ }^{15}$. Pierwsze $z$ nich opierały cała machinę wojenna na pieniądzu, płaciły za wszystko od żołdu po żywność, drugie natomiast wykorzystywały środki pozaekonomiczne, $\mathrm{np}$. pobór, daniny w naturze itp. Chamish Scot przytacza opinię Choiseula, który uważał, że mocarstwami pierwszej rangi mogły być tylko państwa posiadające imperia kolonialne, tzn. - według niego - Hiszpania, Holandia, Francja i Anglia. Inne, takie jak np. Rosja, Austria czy Prusy, w wypadku konfliktu na wielką skalę potrzebowały subsydiów od tych pierwszych ${ }^{16}$. Do państw militarno-fiskalnych zaliczył Scott Prusy, Rosję i po roku 1793 Francję, po części też Sabaudię, natomiast Michael Hochedlinger określał ewolucję monarchii habsburskiej od państwa militarno-fiskalnego do jego militaryzacji, szczególnie po przegranej wojnie siedmioletniej ${ }^{17}$. Janet Hartley omawiając funkcjonowanie machiny wojennej Rosji podkreśla, że podczas wojen napoleońskich doszła ona do wyczerpania swoich zasobów, dlatego tak duże znaczenie miały dla niej subsydia brytyjskie. Pomysłem na utrzymanie armii stały się zakładane kolonie wojskowe, nie uniknięto jednak kryzysu finansowego i krachu w wojnie krymskiej18. Peter H. Wilson opisujac pruskie państwo fiskalno-militarne akcentuje jego ograniczenia i to, że samodzielnie mogło prowadzić tylko krótką, zwycięską wojnę, natomiast prak-

13 „C'étaient des machines faites principalement pour champs de bataille”. Cyt. za: P. A n d e r s o n, L'Etat absolutiste. Ses origines et ses voi, t. I, Paris 1978, s. 33.

14 The Fiscal-Military State...

15 Ch. S t o r r s, op. cit., s. 17 ; H. S c o t t, op. cit., s. 48-50.

16 H. S c o t t, op. cit., s. 47.

17 Ibidem, s. 48-53; M. H o ch ed ling e r, The Habsburg Monarchy: From „Military-Fiscal State” to „Militarization”, [w:] The Fiscal-Military State..., s. 43.

18 J. H a r t le y, Russia as a Fiscal-Military State, 1689-1825, [w:] The Fiscal-Military State..., s. 128-145. 
tycznie od końca wieku XVII Prusy walczyły dzięki otrzymywanym subsydiom. Cały system jednak załamał się ostatecznie w roku $1806^{19}$.

W osiemnastym wieku gwałtownie zwiększają się armie mocarstw europejskich, dochodzi do swoistego wyścigu zbrojeń, co zaważył Monteskiusz i tak opisywał to zjawisko: „Nowa choroba rozszerzyła się po Europie: ogarnęła naszych władców i każe im utrzymywać nadmierna ilość wojsk. Choroba ma swoje nawroty i staje się $z$ konieczności zaraźliwa: skoro tylko bowiem jakieś państwo pomnoży to, co nazywa swoją armią, natychmiast inne państwa pomnażaja swoje; tak iż nie zyskuje się na tym nic, prócz wspólnej ruiny. Każdy monarcha trzyma w gotowości wszystkie wojska, jakimi mógłby rozporzadzać, gdyby ludy jego były w niebezpieczeństwie zagłady; i ten stan wysiłku wszystkich przeciw wszystkim nazywa się pokojem”. Następnie zaś prorokuje, że „mnożąc naszych żołnierzy, będziemy mieli już tylko żołnierzy i będziemy jak Tatarzy"20. Na spełnienie tej przepowiedni Europejczycy czekali do wieku XX.

Spostrzeżenia Monteskiusza potwierdzają badania historyczne. Oblicza się, że w porównaniu $z$ wiekiem XVI, armie w następnym stuleciu były pięciokrotnie większe i były utrzymywane także podczas pokoju. Ponadto państwo zaopatrywało armię w żywność, mundury i uzbrojenie, jednostki wojskowe były umieszczane w koszarach. Gwałtownie wzrosły koszty budowy nowoczesnych fortyfikacji czy utrzymanie floty wojennej21. Ponadto w stuleciu XVIII zrezygnowano $z$ zasady „wojna żywi wojnę" upowszechniona podczas wojny trzydziestoletniej. J. Blake właśnie osiemnasty wiek uznaje za czas właściwej rewolucji militarnej, wtedy właśnie armie europejskie wykazały swoja przewagę wobec innych cywilizacji, np. $\mathrm{w}$ Indiach 22 . Ponadto $\mathrm{w}$ tym stuleciu straciły na znaczeniu armie tatarskie, tak groźne jeszcze wiek wcześniej, a przewaga militarna pozwoliła Rosji zapanować nad wielkim stepem. Wystarczy porównać zachowanie w Rzeczpospolitej sojuszników króla, czyli armii rosyjskiej w czasie Wielkiej Wojny Północnej z okresem wojny siedmioletniej. Koszty prowadzenia wojen wpływały bezpośrednio na

19 P.H. W i 1 s o n, Prussia as Fiscal-Military State, 1640-1806, [w:] The Fiscal-Military State..., s. 95-124.

20 M o n te s ki u s z, O duchu praw, Kraków 2003, s. 203-204.

${ }^{21}$ H. S c o t t, op. cit., s. 29-30.

22 J. B la c k, European Warfare, 1660-1815, London 1994. 
polityke prowadzona przez mocarstwa europejskie. Można w ten sposób tłumaczyć ostrożna politykę R. Walpole’a i kardynała A.H Fleury, gdyż oba kraje były wyczerpane wydatkami poniesionymi na wojnę o sukcesję hiszpańską. Podobnie bierność Francji i Austrii po wojnie siedmioletniej spowodowana była kosztami poniesionymi podczas niej, co doprowadziło do dominacji Rosji i Wielkiej Brytanii na scenie politycznej23. Taki swoisty determinizm historyczny, który nakazuje oceniać politykę międzynarodowa i konflikty zbrojne przede wszystkim $z$ punktu widzenia siły, budzi kontrowersje. $\mathrm{Na}$ przykład Jeremy Black zwraca uwage, że koncepcja państwa fiskalno-militarnego, sprawdza się przede wszystkim w wypadku Wielkiej Brytanii, ale w odniesieniu do innych krajów duże znaczenie miały dyplomatyczne i militarne talenty władców, czego najlepszym przykładem może być Fryderyk II, król pruski24.

W kontekście dyskusji na temat państw fiskalno-militarnych i militarno-fiskalnych można się zastanowić nad rodzajem reform podjętych przez Sejm Czteroletni. Niewątpliwie budowa armii była typowa dla państwa fiskalno-militarnego, podczas gdy w tym rejonie obowiązywał model militarno-fiskalny. Nie zdecydowano się na wprowadzenie poboru, w związku $\mathrm{z}$ czym budowa sił zbrojnych szła bardzo opornie. Dopiero w Księstwie Warszawskim, wzorem Francji, wprowadzono konskrypcję w roku 1808, czego rezultaty były widoczne.

${ }^{23}$ H. S c o t t, op. cit., s. 36, 40.

${ }^{24}$ Ch. S to r r s, op. cit., s. 18. 